\title{
Enzymatic aqueous technology for simultaneous coconut protein and oil extraction
}

\author{
By Beatriz P.M. Sant'Anna, Suely P. Freitas ${ }^{1}$ and Maria A. Z. Coelho ${ }^{2}$
}

\author{
${ }^{1}$ E-mail: freitasp@unisys.com.br \\ ${ }^{2}$ Escola de Química, Universidade Federal do Rio de Janeiro, CT, sl. E-113, 21949-900, \\ Rio de Janeiro - RJ, Brazil
}

\begin{abstract}
RESUMEN
Tecnología enzimática para la extracción simultánea de aceite y proteína de coco.

En este trabajo diferentes enzimas hidroliticos fueron usados para la extracción de aceite y proteína de coco: Celluclast, Termamyl, Viscozyme, Neutrase y Protease producidos por Novo Nordisk. Experimentos preliminares fueron encaminados a la selección de los extractos enzimaticos, de las concentraciones de las enzimas y de los tiempos de incubación. La técnica de análisis de varianza, mediante un delineamiento factorial en tres niveles, fue usada para la optimización de los procesos con relación a los parámetros $\mathrm{pH}$ y razón sustrato/agua. Comparando con la extracción acuosa todos los enzimas hidroliticos incrementan la extracción de aceite y proteína vegetal de coco. Los coeficientes de correlación muestran que el $\mathrm{pH}$ fué el parámetro mas significativo $(p<0,10)$. Las condiciones óptimas para la extracción de aceite y proteína fueron: concentración de las enzimas Viscozyme y Neutrase $0.6 \%(\mathrm{w} / \mathrm{w})$ y $0.3 \%(\mathrm{w} / \mathrm{w})$, respectivamente, tiempo de incubación 30 minutos, razón sustrato/agua 1:6 y pH 7 .
\end{abstract}

PALABRAS-CLAVE: Aceite de coco - Enzima - Extracción acuosa - Proteína de coco.

\section{SUMMARY}

Enzymatic aqueous technology for simultaneous coconut protein and oil extraction.

In this study, the following commercial enzymes were evaluated in the enzymatic extraction of oil and protein from coconut: Celluclast, Termamyl, Viscozyme, Neutrase y Protease. Preliminary experiments were carried out for selection of enzymes, enzyme concentration and incubation time. In order to verify the effects of $\mathrm{pH}$ and water/substrate ratio, a response surface methodology was applied based in a $3^{2}$ full factorial experimental design. The $\mathrm{pH}$ is the most meaningful parameter on oil and protein extraction yields, with a significance level higher than $90 \%$. The maximal extraction yields of oil and protein emulsion (83\%) was reached using Viscozyme $L$ and subsequently Neutrase 1.5 MG at concentrations of $0.6 \%(\mathrm{w} / \mathrm{w})$ and $0.3 \%(\mathrm{w} / \mathrm{w})$, respectively, total incubation time of 60 minutes, substrate/water ratio 1:6 and $\mathrm{pH}$ around 7 (no adjustment).

KEY-WORDS: Aqueous extraction - Coconut oil - Coconut protein - Enzyme.

\section{INTRODUCTION}

Coconut oil is one of the most stable oils what is attributed to its high proportion (90\%) of saturated fats (Inform, 1994). About half of fatty acids in coconut oil are short chains (lauric, myristic and palmitic acids). These medium chain length acids and their derivatives are hydrophilic, which promotes interfacial properties that are valuable in detergents, lubricants, cosmetics and other emulsions applications (Seguro \& Motoki, 1994).

Conventional processes for the extraction of coconut oil involve mechanical treatment, by pressing coconut meat, and a solvent step, that submit the cake for further extraction with $n$-hexane (Christensen, 1991). Although these technologies are economically justifiable, they have certain well-known drawbacks: damage to the environment and quality loss of finished products (e.g. high free fatty acids and lower resistance to rancidity).

Several studies have been carried out on aqueous enzymatic oil extraction (Dominguez et al., 1994; Rosenthal et al., 1996). The enzymatic extraction of vegetable oils, developed at Embrapa - Food Agroindustry reach the high yield extraction of tropical fruits' oil (avocado, pupunha, pequi, tucumã) when the incubation process is based on a combination of pectinolytic enzymes (Freitas et al. 1993). Furthermore, the high yield extraction of seeds oils is obtained on a combination of cellulase and protease enzymes (Freitas et al, 1996).

The enzyme-assisted coconut oil extraction significantly raises the extracted oil yield in aqueous systems (Tano-Debrah, 1997). The main limitation of this process is the low efficiency of the oil separation due to stability of the lipoprotein emulsions. On the other hand, the most important advantage is associated with the simultaneous production of oil and hydrolyzed protein, both largely used in cosmetics formulations. Furthermore, this process allows the removal of the impurities in the aqueous phase.

The present work investigates the effect of relevant operational parameters including enzyme concentration, incubation time, $\mathrm{pH}$ and substrate/ water ratio on coconut protein and oil extraction yield. 


\section{MATERIALS AND METHODS}

Coconut meat used for all experiments was obtained from a local supplier at Rio de Janeiro, Brazil. The proximate composition of the coconut meat and obtained protein-oil emulsions were determined by AOAC methods (1995).

Commercial enzymatic complexes, donated by Novo Nordisk A/S, were employed:

- Viscozyme L (100 FBG/g), a multienzyme complex with cellulase, hemicellulase, arabanase, xylanase and -glucanase activities;

- Termamyl $120 \mathrm{~L}(120 \mathrm{KNU} / \mathrm{g})$, an endoamylase which will hydrolyze 1,4- $\alpha$ - glucosidic linkages in amylose and amylopectin;

- Pectinex 3XL (3000 FDU/g) from Aspergillus niger, with pectinolytic effect;

- Celluclast 1.5L (1500 NCU/g), a cellulase preparation;

- Alcalase (2.4 AU/g) and Neutrase 1.5MG (1.5 AU/g), respectively an alkaline and a neutral protease produced from Bacillus amyloliquefaciens.

\subsection{Enzyme-assisted protein-oil extraction}

For each experiment $100 \mathrm{~g}$ of coconut meat was triturated and blended with warm water $\left(45^{\circ} \mathrm{C}\right)$. The mixture was squeezed and strained through a porous membrane. The milk obtained was heated to $100^{\circ} \mathrm{C}$ for $30 \mathrm{~min}$ and left to cool. The solid residue was blended with water for $5 \mathrm{~min}$ and the mixture was submitted to enzymatic treatment. The enzymatic reactions were carried out with a pectinolytic or cellulolytic enzyme at $50^{\circ} \mathrm{C}$ prior the incubation with a protease at $60^{\circ} \mathrm{C}$, in a shaker under temperature and agitation control. After this step, the mixture was again filtered through a porous membrane, originating a second coconut milk. This milk was mixed with the previously extracted coconut milk and allowed to stand, undisturbed, for 1 hour in order to separate the oily layer. The aqueous layer was drained off and the oil-protein-water mixture was centrifuged at $5000 \mathrm{rpm}$ and $12^{\circ} \mathrm{C}$ during $45 \mathrm{~min}$. This procedure resulted in frozen protein-oil emulsion, released by the enzymytic reaction, which could be then separated from the remaining aqueous layers. The yield was determined by its dry weight in $100 \mathrm{~g}$ of coconut meat (c.m.). Figure 1 illustrates this procedure.

\subsection{Statistical analysis}

Preliminary experiments were developed for selection of enzymes, enzyme concentration, time reaction and incubation parameter levels. Response surface methodology was applied to investigate the effects of $\mathrm{pH}$ and water/substrate ratio, based in a $3^{2}$ full factorial experimental design.

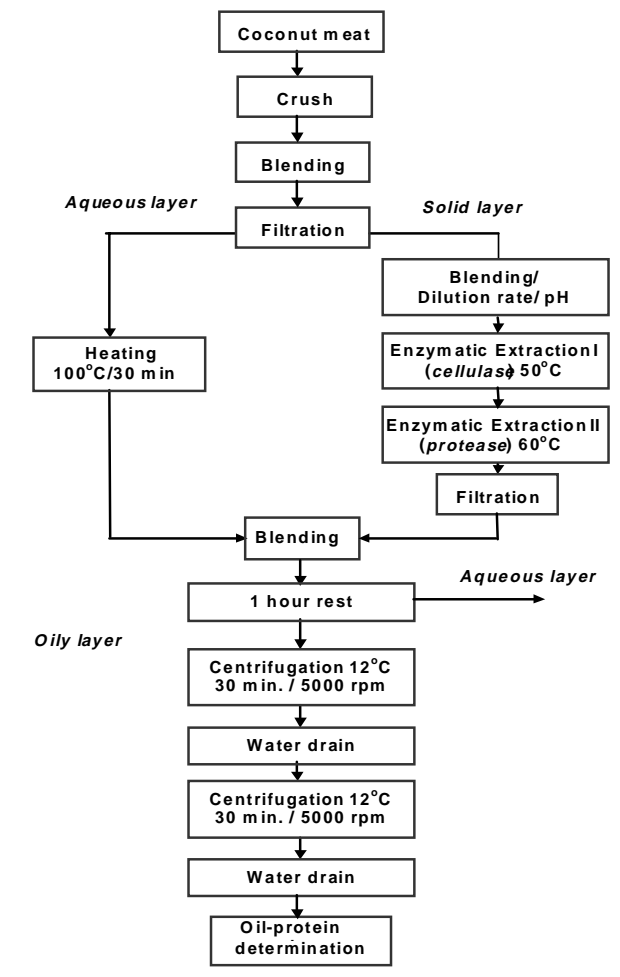

Figure 1

Experimental procedure for coconut protein-oil emulsion extraction in aqueous enzymatic media.

\section{RESULTS AND DISCUSSION}

Results from proximate composition of coconut meat and emulsion obtained indicate that a protein fraction, transferred to aqueous phase during enzymatic process, remains bind to the oil as a lipoprotein emulsions (Table I).

a) Enzyme Selection: Initially, an enzyme selection was carried out based on combinations of protease (Neutrase 1.5MG) and above-mentioned pectinolytic and cellulolytic enzymes. Experiments were carried out in duplicate, with substrate-water ratio of $1: 6$, during 30 minutes for each enzymatic extract employed. The first enzymatic step, at $50^{\circ} \mathrm{C}$, employed $0.3 \%$ of hydrolytic enzyme and the second one, at $60^{\circ} \mathrm{C}, 0.1 \%$ of protease. The selected enzyme combination, as well as the results obtained, are shown in Figure 2. In all cases the enzymatic treatment increased the protein-oil yield as compared with control. The combination between Viscozyme and Neutrase was selected as the most suitable enzymatic treatment reaching an increase of about $60 \%$ with reference to the control.

New experiments were performed in the same conditions, employing Viscozyme $L(0.3 \%)$ and replacing Neutrase by Alcalase $(0.1 \%)$. No significant difference in protein-oil yield was obtained (Figure 2). The Neutrase present the higher activity in the natural $\mathrm{pH}$ of the coconut emulsion and was applied for further incubation parameter selection. 
Table I

Proximate composition of coconut meat and protein-oil emulsion (dry base, $\mathbf{g} / \mathbf{1 0 0 g}$ )

\begin{tabular}{lcc}
\hline & Coconut & Protein-Oil emulsion \\
\hline Oil & 46.41 & 80.88 \\
Protein & 8.20 & 13.38 \\
Ash & 1.68 & 0.38 \\
Fibers & 33.78 & 1.04 \\
Carbohydrates & 9.88 & 4.33 \\
\hline
\end{tabular}

*By difference

b) Enzyme Concentration and Incubation Time: Figure 3 shows the simultaneous effects of the concentrations and incubation times in the yield process for the Viscozyme and Neutrase enzymes. The maximum protein-oil emulsion yield, $50.4 \mathrm{~g}$ by $100 \mathrm{~g}$ of the substrate $(92 \%)$ was observed by enzymatic treatment with $0.6 \%$ Viscozyme $L$ and $0.3 \%$ Neutrase, during incubation time of 30 minutes each in the natural pH (Figure 3). High levels of cellulase and hemicellulase present in Viscozyme $L$, enabled to release the oil and the protein to the aqueous media, due to the rupture of the cell walls that involve the oil globule. Treatment with $0.6 \%$ Viscozyme $\mathrm{L}$ and $0.1 \%$ Neutrase was too effective, although, in this case, the protein-oil emulsion obtained presented higher stability due to lower concentration of protease employed. Protease contributes to enhancing oil extraction, since it breaks the lipoprotein emulsions. Thirty minutes incubation time for each treatment was more efficient in the majority of the combinations tested.

c) $\mathrm{pH}$ and Substrate/Water Ratio: The $\mathrm{pH}$ and substrate/water ratio effects was based in a full factorial experimental design $3^{2}$, in the previous

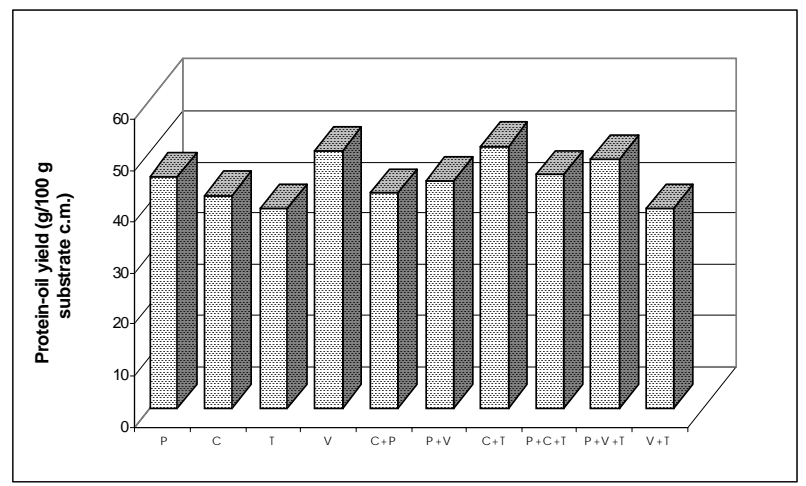

Figure 2

Selection for hydrolytic enzymes: $0.3 \%$ of Pectinase or Cellulase enzyme $\left(50^{\circ} \mathrm{C}\right)$ and $0.1 \%$ of Neutrase $\left(60^{\circ} \mathrm{C}\right)$, in all experiments. $P$-Pectinex 3XL;C - Celluclast; T - Termamyl 120L; $V$ - Viscozyme, $L$

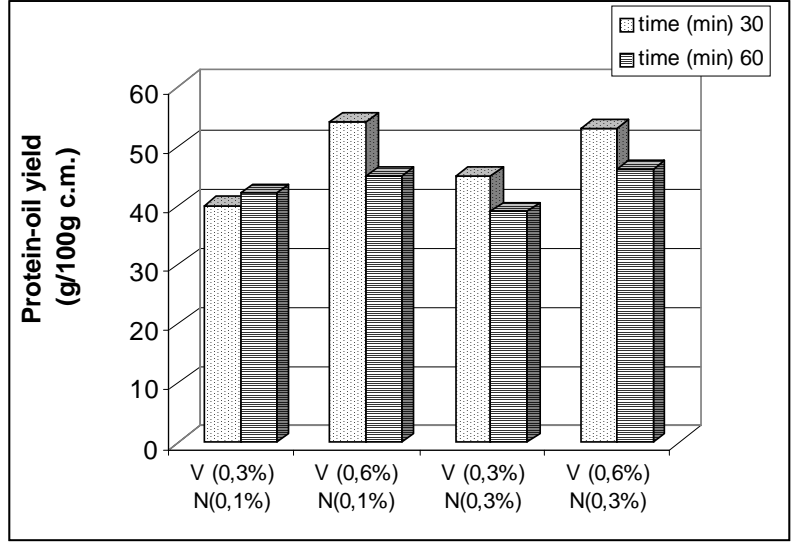

Figure 3

Effects of the incubation time and enzyme concentration in coconut protein-oil emulsion extraction. V - Viscozyme; $\mathrm{N}$ - Neutrase

selected conditions: $0.6 \%$ of Viscozyme $L, 0.3 \%$ of Neutrase $1.5 \mathrm{MG}$ and 30 minutes of incubation time for each enzymatic treatment. Three different $\mathrm{pH}$ levels were tested: 6,7 and 9 , where 7 correspond to the emulsion $\mathrm{pH}$ without any adjustment. To obtain the extreme values, $\mathrm{NaOH} 1 \mathrm{~N}$ and $\mathrm{HCl} 1 \mathrm{~N}$ solutions were added.

It was possible to conclude that an increase in $\mathrm{pH}$ has a negative effect on the enzymatic extraction of coconut protein-oil yield. This is due to higher activities of selected enzymes at natural $\mathrm{pH}$. As can be observed in response surface plots (Figure 4), the $\mathrm{pH}$ profile presents an accentuated curve if compared to the substrate:water one, showing strong dependence between the process yield and $\mathrm{pH}$ (significance level superior to $94 \%$, according to variance analysis). The best condition corresponding to the maximum oil yield was reached in the natural $\mathrm{pH}$ of the mixture and

Fitted Surface; Variable: Protein-oil YIELD (W) 2 3-level factors, 9 Runs:

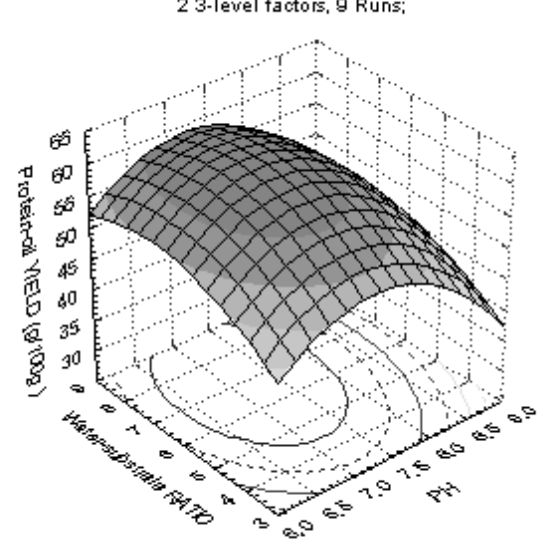

Figure 4

Response Surface for protein-oil emulsion yield as a function of the water/substrate ratio and $\mathrm{pH} .0 .6 \%$ of Viscozyme $\mathrm{L}, 0.3 \%$ of Neutrase 1.5MG and 30 minutes of incubation time for each enzymatic treatment. 
substrate:water ratio 1:9. However, the oil yield at substrate:water ratio $1: 9$ was slightly superior if compared with substrate:water ratio 1:6.

\section{CONCLUSIONS}

This work allowed selecting enzymes and determining extraction parameters that provide best coconut protein-oil yield in the aqueous process. It was possible to conclude that $\mathrm{pH}$ is the most meaningful parameter of the enzymatic process, with a significance level higher than $90 \%$.

The results pointed to the selection of Viscozyme $\mathrm{L}$ and Neutrase 1.5 MG at concentrations of $0.6 \%$ $(\mathrm{w} / \mathrm{w})$ and $0.3 \%(\mathrm{w} / \mathrm{w})$, respectively, incubation time of 30 minutes, substrate/water ratio $1: 6$ and $\mathrm{pH}$ around 7 (no adjustment).

The aqueous enzyme-assisted extraction method has shown to be an effective technique to obtain a higher oil yield. This process generates a practically nonfat fiber, thus proving its efficacy.

\section{ACKNOWLEDGMENTS}

The authors would like to thank the FAPERJ Fundação de Amparo à Pesquisa do Estado do Rio de Janeiro and CNPq - Conselho Nacional de Desenvolvimento Científico e Tecnológico for providing the scholarship. The authors are also grateful to Novo Nordisk which gently provided commercial enzymes.

\section{REFERENCES}

AOAC. Official methods of analysis of the Association of Official Analytical Chemists. 40.ed. Washington, DC, 1995. cap.33, p. 10.

Christensen, F.M. Extraction by aqueous enzimatic process. Inform: International News on Fat, Oils and related Materials. New York, 2, n. 11, 984 - 987, 1991.

Dominguez, H.M.; Núñez, J. and Lema, J.M. Enzymatic pretreatment to enhance oil extraction from fruits and oil seeds: a review. Food Chemistry, 49, 271-286, 1994.

Freitas, S., Lago, R.C.A., Jablonka, F.H. and Hartman, L. Extraction aqueuse enzimatique de l'huile d'avocat a partir de la pulpe fraîche. Revue Française des Corps Gras, França, 41, 365-371, 1993.

Freitas, S.; Hartman, L. and Couri, S. The combined application of extrusion and enzymatic technology for extraction of soya bean oil. Alemanha, Fett and Lipid, Alemanha, 99, 333-337, 1996.

Rosenthal, A., Pyle L.D. and Niranjan, K. Aqueous and enzymatic processes for edible oil extraction. Enzyme Microbiology Technology, 19, Inglaterra, novembro, 402-420, 1996.

Seguro, K. and Motoki, M. Trends in Japanese soy protein research. Inform, International News on Fat, Oils and related Materials, 5, n. 3, 308-313, 1994.

Tano-Debrah, K. and Obta, Y. Aqueous extraction of coconut oil by an enzyme assisted- process. Journal Science Food Agricultural, 74, 497-502, 1997. 